\title{
A Study on Mineralisation of Poly cis 1,4 isoprene (NR) and Synthetic Rubber Gloves (SRG) by the bacterial consortium.
}

\author{
Veenagayathri K*, Ahongsangbam $\mathbf{N}$ \\ Department of Biotechnology, Stella Maris College, Chennai-83, India
}

\begin{abstract}
Objective: The aim of the study was to isolate bacterial consortium from the effluent contaminated site that is used in the mineralizing both natural rubber and synthetic rubber, to optimise the growth conditions for efficient mineralisation and to biochemically characterise and to use 16s RNA sequencing for identifying the bacterial strains.

Materials and Methods: Natural rubber mineralizing bacterial consortium was isolated from effluent contaminated soil. The mineralisation study was performed for five days at every 24 $h$ interval. Optimization studies were performed with different parameters such as varying concentrations of latex, $\mathrm{pH}$, carbon sources, nitrogen sources, mixed carbon and nitrogen source and different temperature. The bacterial consortium mineralizing nr latex was used to mineralize synthetic rubber gloves (SRG) using the same medium for 40 days at every 5 days interval. Effect of pre-treatment was studied by pre-treating the SRG with acetone and exposing it to sunlight. Mineralisation of the Rubber was confirmed by spectrophotometric and Fourier Transform Infra-Red (FTIR) studies.
\end{abstract}

Results: Isolated organism was identified as Enterobater cloacae, Microbacterium laevaniformans and Methylobacterium rhodesianum. Maximum mineralisation of $\left(1.66 \times 10^{-4}\right)$ was shown on the $4^{\text {th }}$ day of incubation. Conformation of NR degradation was done by FTIR analysis that shows the presence of aldehye and ketone produced due to bacterial degradation. The parameters giving optimum results were concentration of latex $-1 \%, \mathrm{pH}-8.5$, carbon source- Xylose, nitrogen source- Ammonium Nitrate, temperature- $37^{\circ} \mathrm{C}$. Maximum mineralisation of synthetic rubber was shown on the $20^{\text {th }}$ day $\left(1.3 \times 10^{-4}\right)$. Among the pre-treated and the untreated samples most prominent distortions were visible on the surface of the sunlight sample when visualized under scanning electron microscopy.

Conclusion: From the present investigation, it can be concluded that the isolated bacterial consortium containing the strains Enterobater cloacae, Microbacterium laevaniformans and Methylobacterium rhodesianum were able to mineralize natural rubber as well as synthetic rubber. Which could be applied in the removal of waste rubber products present in the environment.

Keywords: Enterobacter cloacae, Microbacterium laevaniformans, Methylobacterium rhodesianum, Mineralisation, Natural Rubber, 16s rRNA sequencing.

Accepted on September 12, 2017

\section{Introduction}

Natural rubber latex is produced by over 2,000 plant species, and its main constituent is poly (cis-1,4-isoprene), a highly unsaturated hydrocarbon $[1,2]$.

Gutta-perch is an natural rubber sources composed of trans1,4-polyisoprene, a structural isomer that has similar, but not identical, properties. Natural rubber latex (NRL) is a particular kind of rubber derived from the milky sap of the Hevea brasiliensis tree that is refined and treated to form the raw liquid latex used to make gloves. It is also used to manufacture a number of products as diverse as tyres, clothing, medical products and toys [3].

India, Thailand and Vietnam are among the largest natural rubber producing countries. In India Kerala state contributes about $90 \%$ of India's total production of natural rubber. Both states of Kerala and Tamil Nadu contribute around $86 \%$ of the growing area of natural rubber. Rubber usage is one of the most important worldwide waste disposal problem [4]. After the usage of these natural rubber products, their disposal is a major worldwide solid waste problem. Rubber has a complex structure because of the chemical cross linking. It becomes very difficult to simply melt and reshape these rubber products, as it can be done with thermoplastic materials like polyethylenes and polypropylenes. Reuse of these rubber materials is possible with special processes like grinding, pyrolysis and other thermal methods. During the different treatment methods, the material may be broken down in to a certain extent and but it will not have the original characters. Natural rubber products like tires contain around $1.5 \%$ by weight of hazardous substances [5].

Rubber products such as balloons, rubber sheets, bags, tubes and gloves, bands and others, are freely thrown in to the environment, 
which possesses great threat to the animals. Rubber being a natural polymer when consumed by animals may lead to death. The only way to scrap the rubber is incineration; however, the process is not simple, as the incinerator must be designed to control air emissions and should be equipped with scrubbers to remove contaminants such as chlorine.

Chlorine emissions generally come from burning of waste rubber products and scrap that contain chloroprene polymers. The scrubbers generate an acidic product that may have to be neutralized prior to discharge. Almost all rubber compounds contain some type of fillers, either carbon blacks, clays, calcium carbonates or hydrated silica compounds. When these rubber compounds are burned, they generate ash which may contain heavy metals, like zinc. Thus, incineration is not only good solution for handling rubber waste [6].

The only way of overcoming such environmental problem is provided by microbial transformation of rubber into useful products [7]. There is some most specific importance of biotechnological processes when compared to chemical and physical ones as it is eco-friendly and less cost involved. Biotransformation of compounds does not produce any harmful or toxic chemicals and is normally not energy intensive. However, there are still some obstacles, mostly sensitivity of microorganisms toward many chemical substances, including rubber additives, which are used to improve stability and function of tires over a wide range of temperature.

Deterioration of rubber products using microbes has attracted much interest in solving the environmental problem [8], and many studies have been carried out on the degradation of both pure rubber elastomers and vulcanized rubber products. Further it becomes important to study the molecular and biochemical aspects in the field of microbial degradation of natural and synthetic polyisoprenoids in order to find ways to solve the global problem of excess rubber material [9].

Biodegradation of polyisoprene products has been studied since the beginning of the last century, as the treatment method is more natural and clean but nearly all of the studies were restricted to rubber degradation. Many efforts were undertaken to isolate suitable rubber-degrading bacteria and to unravel the molecular mechanism of biodegradation. With solid-state polymers (vulcanized and unvulcanized rubber) or NR latex as substrates, more than 100 bacteria were isolated [10-14].

As this rubber material are difficult to destroy or reuse, there is a need to find out more ways that are environmental friendly and that takes lesser time in the degradation process. Hence this present work focuses on mineralisation of natural rubber by bacterial consortium isolated from textile effluent contaminated soil. The isolated bacterial consortium was optimised for their growth conditions and their mineralisation ability was confirmed by FTIR analysis. The bacterial consortium was optimized for $(\mathrm{pH}$, temperature, carbon, nitrogen and mixed carbon and nitrogen) and for optimum concentration of mineralisation of natural rubber. The isolated consortium was also applied in the mineralisation of Synthetic Rubber Gloves (SRG). Synthetic rubber mineralisation was analysed using scanning electron microscopy. Further the bacterial strains present in the consortium were identified by biochemical characterisation and 16s rRNA sequencing. Such isolated bacterial consortium could be applied in the treatment of rubber contaminated soil.

\section{Materials and Methods}

\section{Collection of latex material}

The liquid sample of latex was collected from rubber plantation area in Wayanad. The latex was mixed with an ammonium solution to prevent its coagulation while it is being transported from its collection site.

\section{Collection of synthetic rubber sample}

Synthetic rubber sample was obtained from Kimberly-Clark purple Nitrile-xtra powder-free exam gloves which were supplied by Sudhagar Biologicals, Chennai.

\section{Collection of soil samples}

The soil samples were collected from textile effluent contaminated soil under aseptic conditions in ziplock covers. It was transported to the laboratory immediately and preserved in refrigerator for further analysis.

\section{Acclimatization}

The bacterial consortium mineralizing the Natural Rubber was isolated in the present study by acclimatizing the consortium in $100 \mathrm{ml}$ of mineral salts medium (MSM). Media composition of the mineral salts medium (g/l) Di-potassium hydrogen phosphate $\left(\mathrm{K}_{2} \mathrm{HPO}_{4}\right)-1.0$, magnesium sulphate $\left(\mathrm{MgSO}_{4} 7 \mathrm{H}_{2} \mathrm{O}\right)-0.5$, potassium nitrate $\left(\mathrm{KNO}_{3}\right)-1.0$, distilled water $\left(\mathrm{H}_{2} \mathrm{O}\right)-1000 \mathrm{ml}$, $\mathrm{pH} 7.0$ [15]. The MSM was sterilised and supplemented with $1 \%$ latex solution (Figure 1). $5 \mathrm{~g}$ of the collected soil sample was added to the medium and it was incubated for $48 \mathrm{~h}$. The bacterial strains in the consortium were morphologically observed under light microscope every $24 \mathrm{~h}$ interval. The culture from MSM was serially diluted and pour plate technique was performed on sterile mineral salts medium agar plates for the dilutions $10^{-6}$, $10^{-7}$ and $10^{-8}$. A viable cell count was performed by plating the bacterial strains in MSM and agar containing latex. Bacterial strains which were morphologically different were identified and pure cultures were made. These were used for further experiments and also stored as glycerol stock.

\section{Determination of the molecular weight of the NR-latex solution}

For evaluation of the average molecular weight of the collected

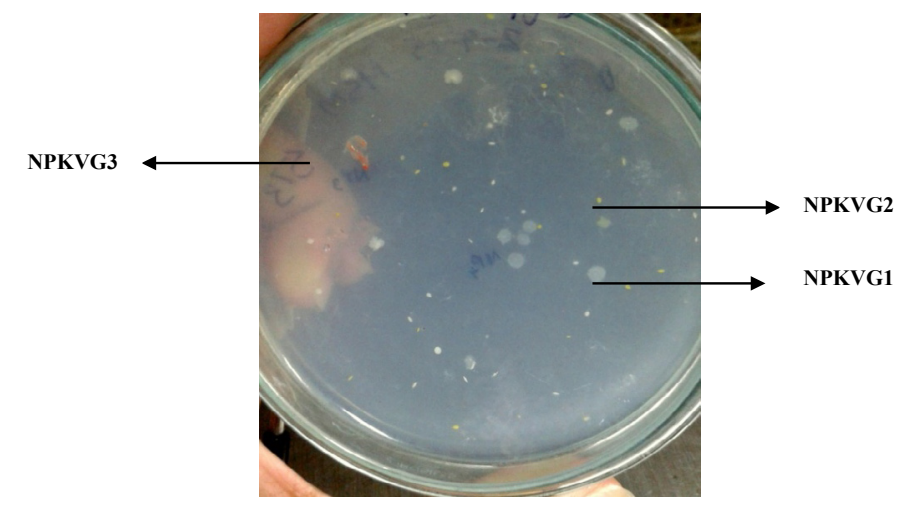

Figure 1. Enriched bacterial consortium in MSM agar plate containing latex. 
NR-latex solution a capillary Ubbelohde viscometer was used. First stock of $2 \%(\mathrm{w} / \mathrm{v})$ concentration of latex solution was prepared. Then it was diluted with distilled water at different concentrations like $0.8,1.6,2.4$, and $3.2(\mathrm{v} / \mathrm{v})$. Then according to the time taken by each of those samples to reach their specific end point in the viscometer, the specific viscosity was calculated for each sample.

The formula used for the calculation of the specific viscosity is given by:

Specific viscosity $\eta_{\mathrm{sp}}=\mathrm{t}_{\mathrm{s}}-\mathrm{t}_{\mathrm{o}} / \mathrm{t}_{\mathrm{o}}$

Where, $\mathrm{t}_{\mathrm{s}}$ is the time taken by the sample and $\mathrm{t}_{\mathrm{o}}$ is the time taken by distilled water. The intrinsic viscosity $(\eta)$ was calculated to be 0.405 .

\section{Calculation of the molecular weight of the natural rubber}

The method widely used in the determination of the molecular weight is based upon the determination of the intrinsic viscosity [ $\eta$ ] of a polymer in the solution through measurements of the solution viscosity. Molecular weight is related to [ $\eta]$ by the mark-houwink equation given as,

$[\eta]=\mathrm{kmv}^{\alpha}$

Where, mv is the viscosity - average molecular weight. Both $\mathrm{k}$ and $\alpha$ are empirical constants that are specific for a given polymer, solvent and temperature. The molecular weight of the natural rubber latex used was found to be 21379.62 .

\section{Determination of the mineralization rate of the natural rubber latex and growth pattern of the bacterial consortium}

The mineralization rate of natural rubber latex was determined by the titrimetric method [16] and the growth pattern of the bacterial consortium was observed by analyzing the growth OD every $24 \mathrm{~h}$ for 5 days. Evidence for mineralization of the poly (cis-1,4-isoprene) and poly (trans-1,4-isoprene) hydrocarbon chain was obtained by the determination of the respiratory $\mathrm{CO}_{2}$ released during the cultivation of the cells in the presence of Poly (cis-1,4-isoprene) as sole carbon source. Determination was carried out in a tightly closed glass bottles by using the property $\mathrm{Ba}(\mathrm{OH})_{2}$ to precipitate $\mathrm{CO}_{2}$ into $\mathrm{BaCO}_{3}$. $50 \mathrm{ml}$ of mineral salts medium was sterilized and dispensed in sterile bottles with $1 \%$ latex. Further bacterial consortium was inoculated in the respective bottles. The bottles were connected to tubes containing $15 \mathrm{ml}$ of $0.2 \mathrm{M}$ Barium Hydroxide solution. Bottles containing the MSM and test tubes containing $\mathrm{Ba}(\mathrm{OH})_{2}$ where fixed with silicon tubes and sealed with parafilm to collect the $\mathrm{CO}_{2}$. The bottles containing mineralised latex were quantified by estimating the presence of $\mathrm{BaCO}_{3}$ which was titrated against $1 \mathrm{~N} \mathrm{HCl}$. Mineralization was calculated using the following formula:

Mineralization $\left(\% \mathrm{CO}_{2}\right)=$ Required amount of $\mathrm{HCl}(\mathrm{ml}) \times 1 / \mathrm{C}$ content of amount of poly $(1,4$ - isoprene) applied $(\mathrm{mmol}) \times 2$.

As an indicator, phenolphthalein was added and the end point was determined by alteration of the colour from pink to colourless $[16,17]$.

\section{Mineralization of different concentrations of latex}

To study the mineralization of different concentrations of NR latex $(1 \%, 2 \%, 3 \% \& 4 \%)$, the bacterial consortium was inoculated in each of the concentrations mentioned. Then the MSM containing bottles were connected to the tubes containing $\mathrm{Ba}(\mathrm{OH})_{2}$ using silicon tubes and these were properly sealed with parafilm. The set up was kept for incubation at room temperature. Mineralization was studied and quantitative estimation of $\mathrm{BaCO}_{3}$ was done by titrating it against $1 \mathrm{~N} \mathrm{HCl}$ [16] every $24 \mathrm{~h}$ for 5 days.

\section{Effect of different $\mathrm{pH}$ and temperature on the growth of bacterial consortium}

Effect of varying $\mathrm{pH}$ and temperature was studied on the growth and mineralisation by the bacterial consortium, media was prepared in different $\mathrm{pH}$ ranging from 8 to $9.5(8,8.5,9,9.5)$ and different temperatures $\left(22^{\circ} \mathrm{C}, 37^{\circ} \mathrm{C}, 45^{\circ} \mathrm{C}\right)$. Mineralization of the latex was studied and quantitative estimation of $\mathrm{BaCO}_{3}$ was done by titrating it against $1 \mathrm{~N} \mathrm{HCl}$ [16] every $24 \mathrm{~h}$ interval for 5 days.

\section{Effect of varying the carbon and nitrogen sources on the growth of bacterial consortium}

At the optimum concentration of NR 1\%, effect of different carbon and nitrogen sources were studied. The carbon sources (sucrose (S), maltose (M), xylose (X), maltose (M)) and nitrogen sources (peptone $(\mathrm{P})$, ammonium nitrate $(\mathrm{AN})$, yeast extract $(\mathrm{Y})$, ammonium oxalate $(\mathrm{AO})$ ) of $1 \%$ concentration was supplemented in the MSM and which was inoculated with the bacterial consortium. Mineralization was studied and quantitative estimation of $\mathrm{BaCO}_{3}$ was done by titrating it against $1 \mathrm{~N} \mathrm{HCl} \mathrm{[16]} \mathrm{every} 24 \mathrm{~h}$ of interval for 5 days. Further studies were carried out with optimum concentrations of mixed carbon and nitrogen sources as mentioned above.

\section{Conformation of natural rubber mineralization by Fourier Transform Infrared Spectroscopy (FTIR)}

Chemical changes that arose directly on the natural rubber surface as a result of the mineralization were determined using FTIR spectroscopy. The natural rubber samples were studied in transmittance spectra in IR range 4000 to $400 \mathrm{~nm}$ [18].

\section{Acclimatization of NR mineralizing bacterial consortium to degrade SR gloves}

Synthetic Rubber Gloves $(\mathrm{SRG})$ pieces of $5 \mathrm{~mm}(\mathrm{~L} \times \mathrm{B})$ were used in the mineralization study. Acclimatized NR mineralizing bacterial consortium was inoculated in the SRG containing MSM for a period of 10 days. Further the growth of the bacterial consortium was observed every 24 hours under light microscopy. Mineralization study was performed with SRG as a sole carbon source for every 5 days interval for 40 days. This was kept at $37^{\circ} \mathrm{C}$ and agitated for $120 \mathrm{rpm}$ on a rotary shaker. After incubation the distortion on the synthetic rubber was observed under Scanning Electron Microscopy.

Effect of pre-treatment of the synthetic rubber (SR) gloves for mineralisation

Synthetic rubber present in the MSM was pre-treated by exposing 
Citation: Veenagayathri K, Ahongsangbam N. A Study on Mineralisation of Poly cis 1,4 isoprene (NR) and Synthetic Rubber Gloves (SRG) by the bacterial consortium. Environ Risk Assess Remediat. 2017;1(3):47-58

to sunlight for 3 days for every $3 \mathrm{~h}$ and with acetone $(2 \mathrm{ml})$ till it was completely evaporated. To study the mineralization of $\mathrm{SR}$, the pre-treated synthetic rubber gloves pieces and untreated synthetic rubber were inoculated in the MSM containing bacterial consortium in each flask in duplicates. Synthetic rubber gloves inoculated in MSM in the absence of bacterial consortium served as abiotic control. The ability of bacterial consortium to utilise the SR as carbon source in the MSM was observed by staining with Schiff's reagent and visualising under scanning electron microscopy.

\section{Staining of rubber degrading colonies by Schiff's reagent method}

The actively growing colonies of the bacterial consortium on the rubber surface were visualized clearly by staining with Schiff's reagents [19]. The purple colour produced by the reagent shows the evidence that polyisoprene oloigomers containing aldehyde group were produced and accumulated during the microbial mineralization of rubber [20].

\section{Scanning electron microscopy (SEM) for analysis of distortion in SRG}

SRG after incubation with the bacterial consortium were taken and prepared for SEM by an initial fixation in $2 \%$ Glutaraldehyde. Samples were dehydrated in graded series of ethanol 30, 50, 60, 70, 80, 90 and with absolute ethanol. The samples were let to dry. The samples were mounted on aluminium stubs using electrically conducting carbon and sputter coater with approximately $15 \mathrm{~nm}$ gold with argon gas as the ionising plasma. Imaging was performed using a scanning electron microscope [21].

\section{Morphological and biochemical characterisation}

Gram staining, motility test and Scanning Electron Microscopy (SEM) were performed to study the morphological characteristics of the bacterial isolates following which biochemical characterization was done (with Himedia, India) to identify the phenotypic characters. Catalase, Oxidase, Urease, IMViC, Indole production, MRVP, Citrate utilization and Triple Sugar Iron agar tests were performed to determine the biochemical characteristics of the isolate. After $24 \mathrm{~h}$ incubation at $37^{\circ} \mathrm{C}$, the colour change observed was determined as positive/negative result. Genus level identification of the unknown bacterial strain was accomplished by using Bergey's manual of systematic bacteriology [22]. Antibiotic sensitivity of the bacterial species was also tested by Kirby Bauer's procedure (1966) to find out the resistant pattern to various antibiotics (Table 1).

\section{Molecular characterisation of individual isolates}

Chromosomal DNA was isolated from the pure strain by the standard phenol/chloroform extraction method. The 16s rRNA gene was amplified from the chromosomal DNA using polymerase chain reaction (PCR). The sequencing of the target gene was done using Bigdye chemistry, and performed as per the manufacturer's protocols (Applied Biosystems $3730 \times 1$ DNA analyzer)

\section{Phylogenetic analysis}

The output file of sequence alignment was used to compute phylogenetic trees for aligned sequences of $16 \mathrm{~s}$ r-DNA
Table 1. Morphological and Biochemical characterisation of the isolated bacterial strain.

\begin{tabular}{|c|c|c|c|}
\hline \multirow{2}{*}{ Tests } & \multicolumn{3}{|c|}{ Isolated strains } \\
\hline & NPKVG 1 & NPKVG 2 & NPKVG 3 \\
\hline Motility & + & - & - \\
\hline Gram staining & - & + & - \\
\hline Cell shape & Rods & Rods & Rods \\
\hline Catalase & + & + & + \\
\hline Urease & + & - & + \\
\hline Indole & - & - & - \\
\hline Methyl red & - & + & - \\
\hline Voges-proskauer & + & + & + \\
\hline Citrate utilisation & + & + & + \\
\hline Starch hydrolysis & + & + & + \\
\hline Triple sugar-iron agar & $\begin{array}{c}\text { Alkaline slant and } \\
\text { alkaline butt }\end{array}$ & - & - \\
\hline Oxidase & - & + & + \\
\hline
\end{tabular}

sequencing results of the three bacterial strains (NPKVG1, NPKVG2 and NPKVG3). Neighbour joining method was used for tree building with MEGA 6 software. To access the reliability of the phylogenetic tree, MEGA provides bootstrap test which used the bootstrap resampling strategy. The user has to input the number of replicates. In this experiment, 500 replicates were used.

\section{Results}

\section{Isolation and screening NR degrading bacterial consortium}

The NR mineralizing bacterial consortium was enriched and isolated from textile effluent contaminated sites. The NR mineralizing bacterial consortium which are morphologically different were identified and pure cultures of individual strains were made. Initially six bacterial strains were screened and isolated out of which only three strains were able to mineralise natural rubber latex. These three bacterial strains were named NPKVG1, NPKVG2 and NPKVG3 were able to grow on the MSM agar plate containing latex was used for further experiments. Figure 1 shows the growth of isolated bacterial consortium at dilution $10^{-7}$ in MSM agar plate.

\section{Growth of the bacterial consortium on NR}

The isolated bacterial consortium was inoculated in mineral salts medium with latex and their growth pattern was studied. Figure 2 shows the growth pattern of isolated bacterial consortium. The maximum growth was observed on the $3^{\text {rd }}$ day

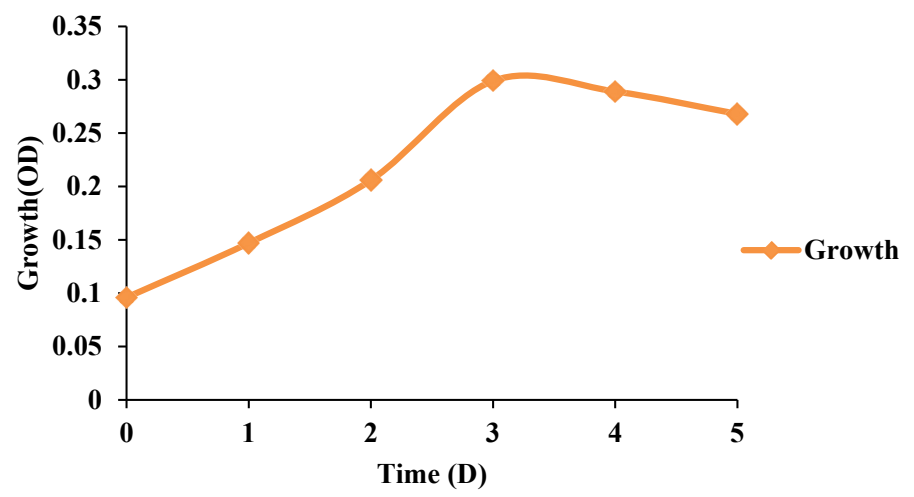

Figure 2. Growth of bacterial consortium on natural rubber latex. 


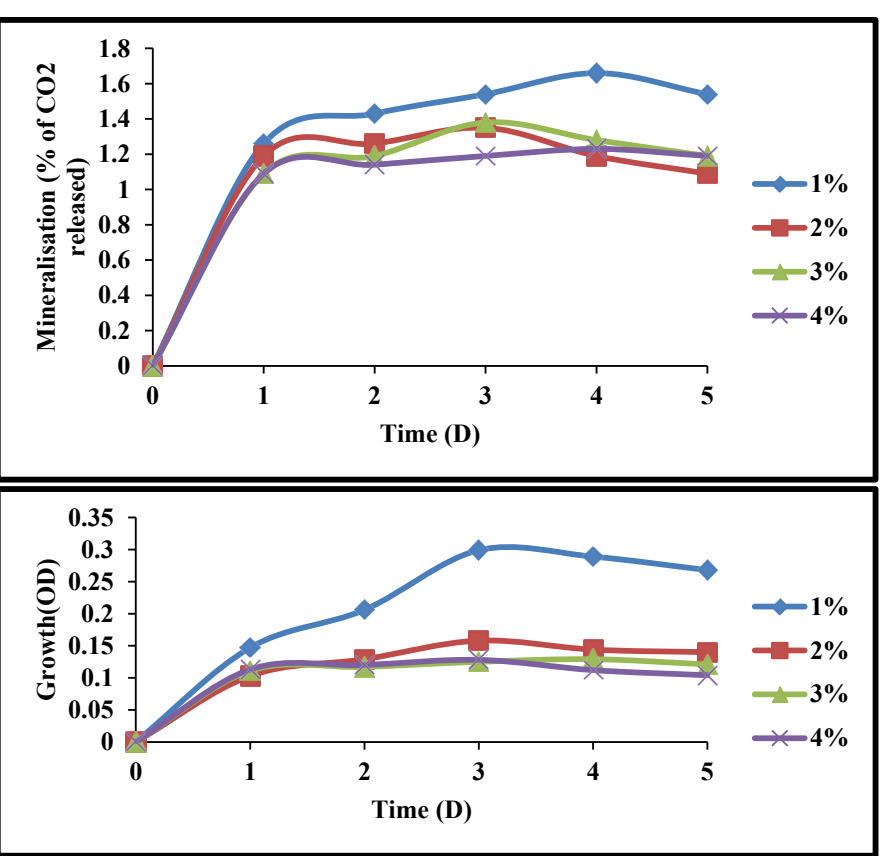

Figure 3. Mineralization of different concentrations of Natural Rubber latex by the Bacterial consortium.

(0.299). The growth of bacterial consortium decreased from $4^{\text {th }}$ day $(0.289)$ and finally depleted from the $5^{\text {th }}$ day $(0.268)$ of incubation. Hence further mineralisation studies of NR by the bacterial consortium were carried out for the end of 5 days and the mineralization were analyzed at $24 \mathrm{~h}$ interval.

\section{Mineralization of different concentrations of natural rubber latex}

To study the growth of the bacterial consortium on different concentrations of latex $(1 \%, 2 \%, 3 \%, 4 \%$ and $5 \%)$, bacterial consortium was inoculated in Mineral Salts Medium containing different concentrations of latex. Figure 3 shows mineralization and growth on different concentrations of latex by the bacterial consortium. The bacterial consortium showed maximum growth on the $3^{\text {rd }}$ day $(0.299)$ and mineralization of $(1.66 \times$ $10^{-4}$ ) on the $4^{\text {th }}$ day on $1 \%$ of latex concentration. At $2 \%$ and $3 \%$ concentration of $\mathrm{NR}$, the mineralization of latex varied from $\left(1.35 \times 10^{-4}\right)$ and $\left(1.38 \times 10^{-4}\right)$ on $3^{\text {rd }}$ day respectively with growth OD of 0.158 on $3^{\text {rd }}$ day, 0.129 on $4^{\text {th }}$ day respectively. At $4 \%$ concentration of latex the bacterial consortium showed a maximum mineralisation of $\left(1.23 \times 10^{-4}\right)$ on $3^{\text {rd }}$ day with a growth OD of 0.128 .

\section{Effect of varying $\mathrm{pH}$}

To study the growth of the bacterial consortium and mineralization of latex on different $\mathrm{pH}(8,8.5,9$ and 9.5) of MSM the bacterial consortium was inoculated in MSM with $1 \%$ latex solution at different $\mathrm{pH}$. Figure 4 shows the growth of bacterial consortium and mineralization of latex at different $\mathrm{pH}$. Maximum growth and mineralization was seen in $\mathrm{pH} 8.5$. Maximum growth on $3^{\text {rd }}$ day $(0.192)$ and mineralization of $(1.3$ $\times 10^{-4}$ ) on the $4^{\text {th }}$ day was observed.

\section{Effect of varying the temperature}

To study the growth of the bacterial consortium and mineralization of latex on different temperature $\left(28^{\circ} \mathrm{C}, 37^{\circ} \mathrm{C}\right.$, $45^{\circ} \mathrm{C}$ ), the bacterial consortium was inoculated in mineral salts medium with $1 \%$ latex solution and incubated at different temperature. Figure 5 shows the growth of bacterial consortium and mineralization of latex at different temperatures. Efficient growth and mineralization was observed at $37^{\circ} \mathrm{C}$, maximum growth on $4^{\text {th }}$ day $(0.211)$ and mineralization of $\left(1.59 \times 10^{-4}\right)$ on the 3 rd day.

\section{Optimization of different carbon and nitrogen sources at $1 \%$ natural rubber}

To study the effect of different carbon sources (sucrose(S), lactose $(\mathrm{L})$, xylose $(\mathrm{X})$, and maltose $(\mathrm{M})$ ) and nitrogen sources (peptone $(\mathrm{P})$, ammonium nitrate $(\mathrm{AN})$, yeast $\operatorname{extract}(\mathrm{Y})$, ammonium oxalate( $\mathrm{AO})$ ) on the growth of the bacterial consortium and mineralization of latex. The carbon and nitrogen sources were inoculated at $1 \%$ concentration.

\section{Effect of different carbon sources on mineralisation of $N R$}

Figure 6 shows the growth and mineralization in different carbon sources. Efficient growth and mineralization was observed in the presence of Xylose as the carbon source, maximum growth on $3^{\text {rd }}$ Day $(0.180)$ and mineralization of $\left(1.54 \times 10^{-4}\right)$ on the 3rd Day.

\section{Effect of different nitrogen sources on mineralisation of $N R$}

Figure 7 shows the growth and mineralization of natural rubber in different nitrogen sources. Efficient growth of bacterial consortium and mineralization of latex was observed in the presence of ammonium nitrate as the nitrogen source, maximum growth on $3^{\text {rd }}$ day $(0.404)$ and mineralization of $\left(1.71 \times 10^{-4}\right)$ on the $5^{\text {th }}$ day.

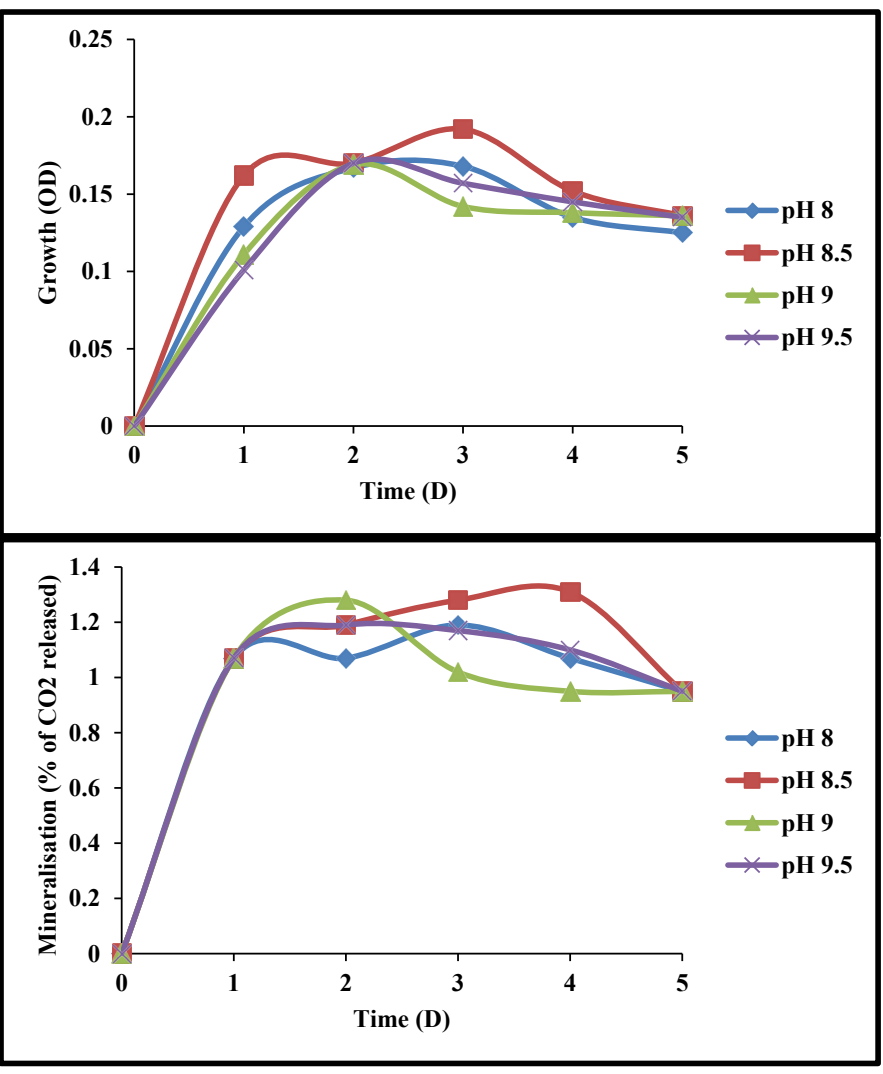

Figure 4. Effect of different $p H$ on mineralization of $N R$. 


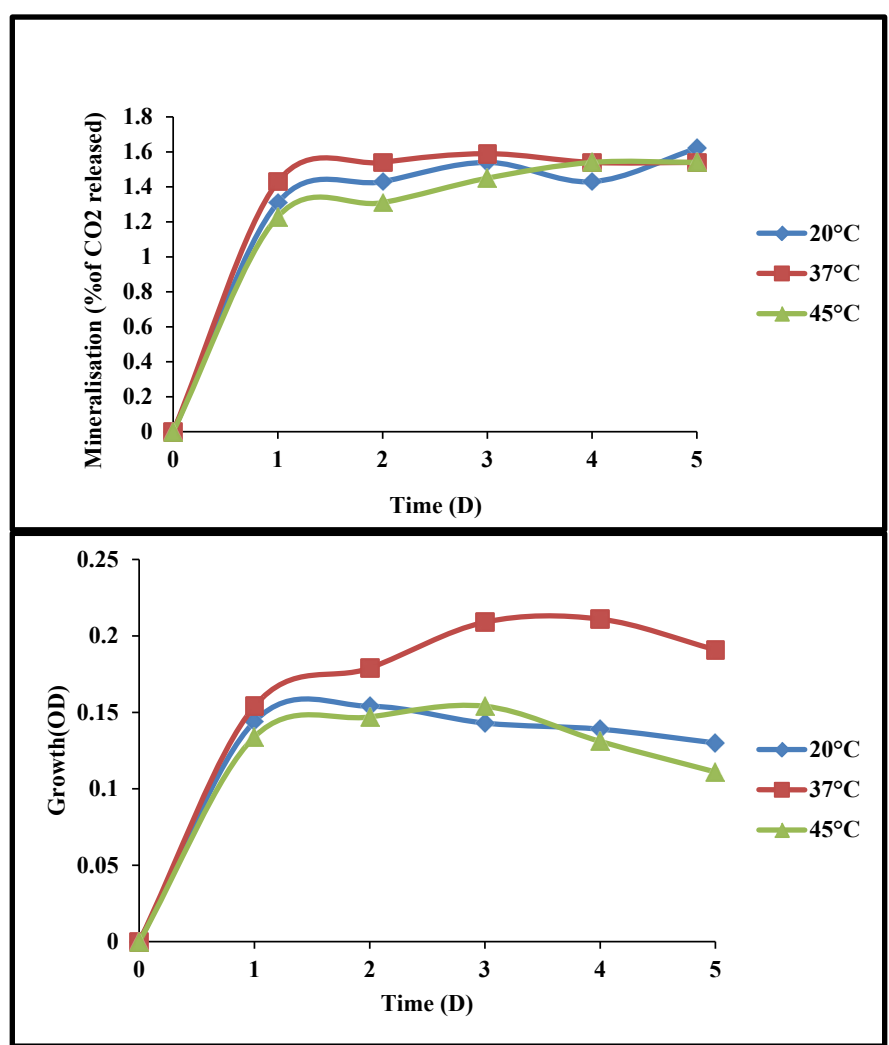

Figure 5. Effect of varying the temperature on mineralization of $n$ r.
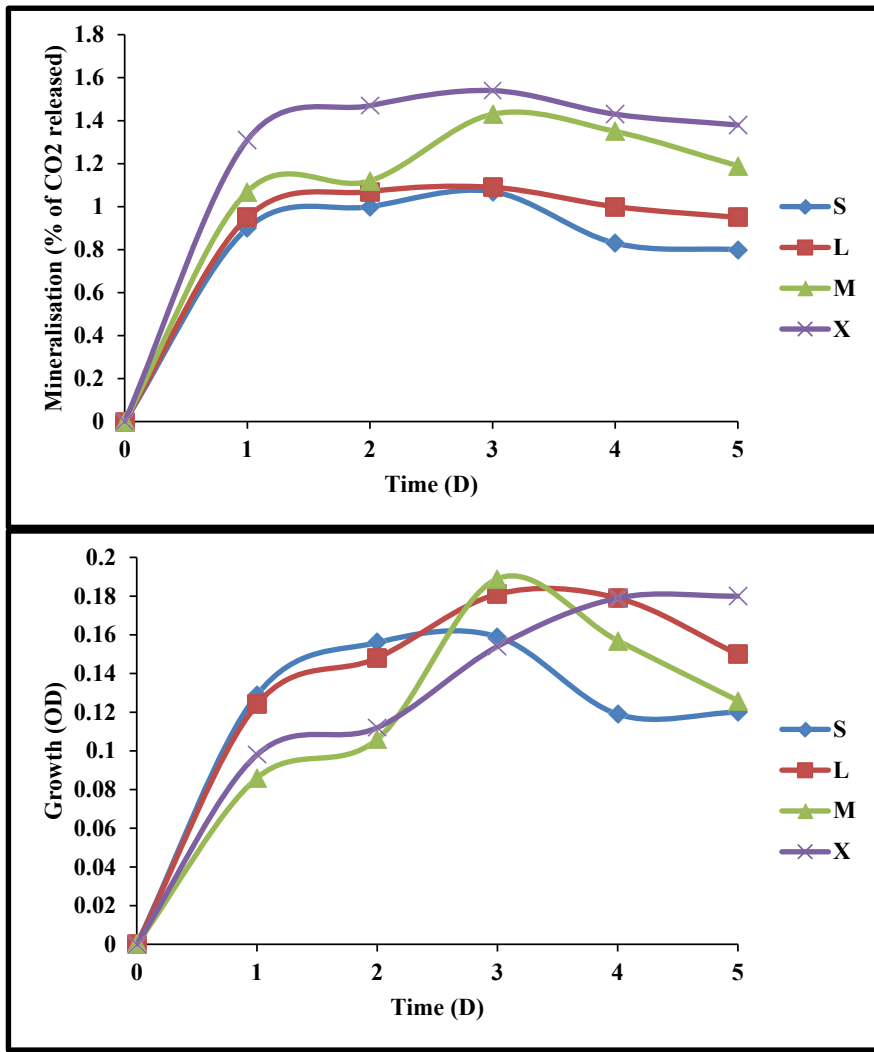

Figure 6. Effect of different carbon sources on mineralization of $N R$.

\section{Effect of mixed carbon and nitrogen sources on mineralization of $N R$}

Figure 8 shows the growth and mineralization in optimum mixed carbon and nitrogen sources. Efficient growth of bacterial

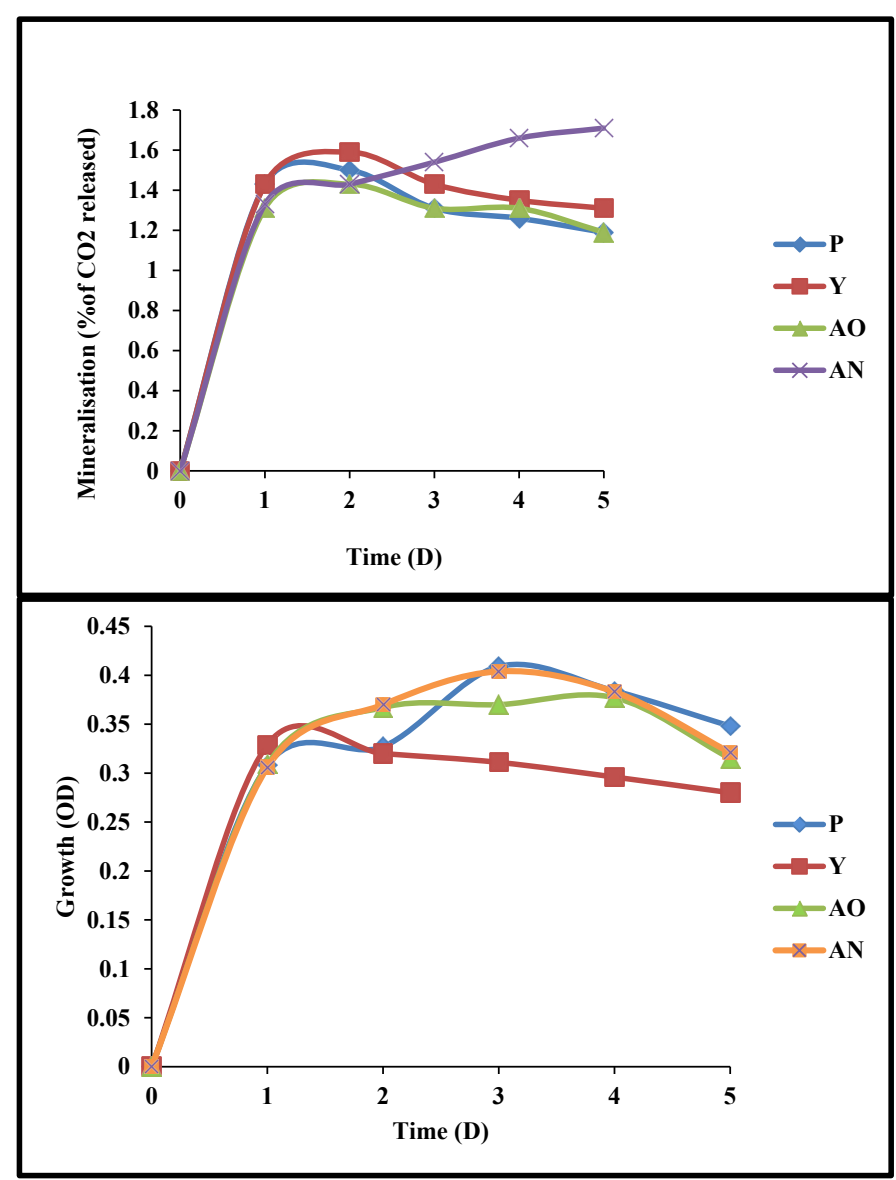

Figure 7. Effect of different nitrogen sources on mineralization of $N R$.

consortium and mineralization of latex was observed in the presence of xylose as the carbon source and ammonium nitrate as the nitrogen source, maximum growth on $3^{\text {rd }}$ day $(0.194)$ and mineralization of $\left(1.54 \times 10^{-4}\right)$ on the $4^{\text {th }}$ day was observed.

\section{Conformation of natural rubber degradation by Fourier Transform Infrared Spectroscopy (FTIR) analysis}

Fourier Transform Infrared Spectroscopy (FTIR) analysis was done to detect the mineralization of poly-cis-isoprene after culturing in MSM, on the basis of changes in the functional groups. FTIR spectrum (Figure 9) on the $1^{\text {st }}$ day of mineralisation of NR showed wavelength of $1531.55 \mathrm{~cm}^{-1}$ and $1670.43 \mathrm{~cm}^{-1}$ having C-H Stretching of medium intensity and C-O stretching of strong intensity respectively. One the same day of incubation wavelength of $1678.14 \mathrm{~cm}^{-1}$ having C-N Stretching of variable intensity was shown. On the $5^{\text {th }}$ day of mineralisation of NR showed wavelength of $1532.51 \mathrm{~cm}^{-1}$ and $1689.72 \mathrm{~cm}^{-1}$ having $\mathrm{C}-\mathrm{H}$ Stretching of medium intensity and C-N stretching of variable intensity respectively. Wavelength of $1674.28 \mathrm{~cm}^{-1}$ having C-O Stretching of very strong intensity was also shown on the same day. Thus, indicating the presence of aldehydes and ketones formed during the mineralisation of NR.

\section{Acclimatization of NR mineralizing bacterial consortium to degrade SR gloves}

The Bacterial consortium acclimatized in NR containing MSM was grown in the MSM containing Synthetic Rubber Gloves. The flask containing SRG that were not inoculated with Bacterial 


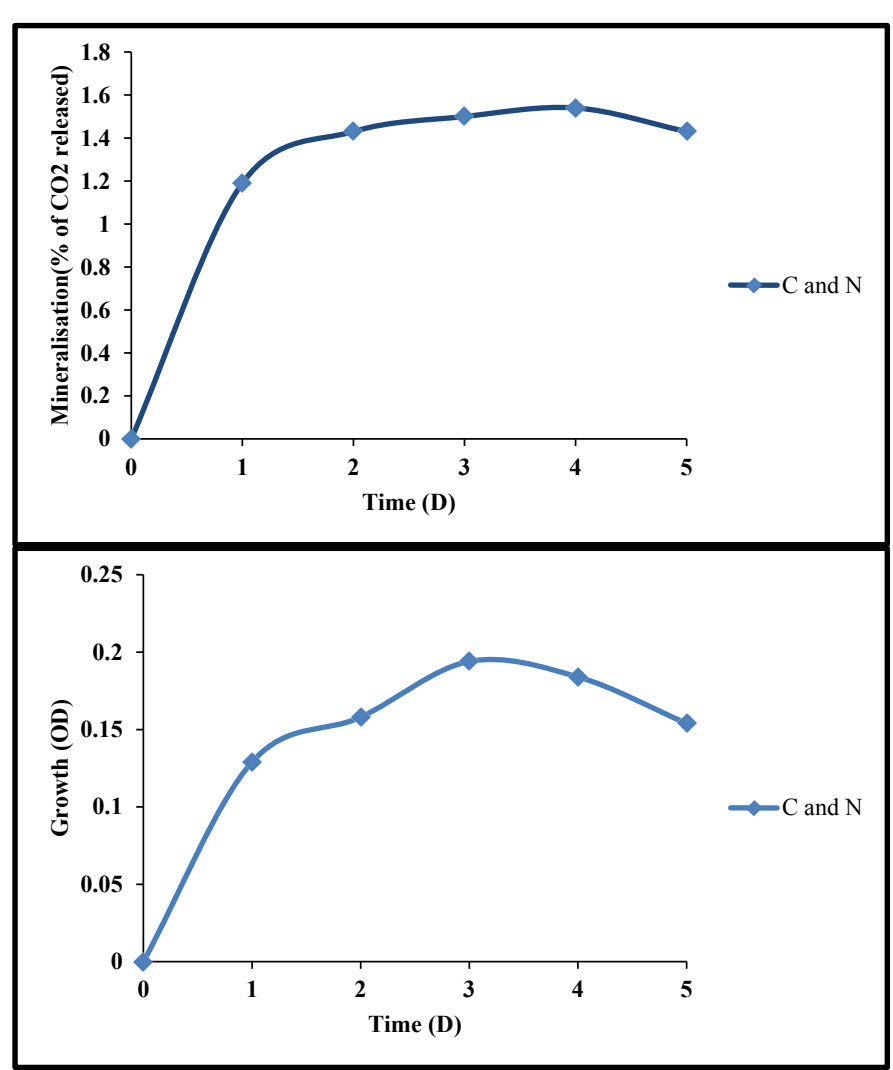

Figure 8. Effect of mixed carbon and nitrogen sources on mineralization.
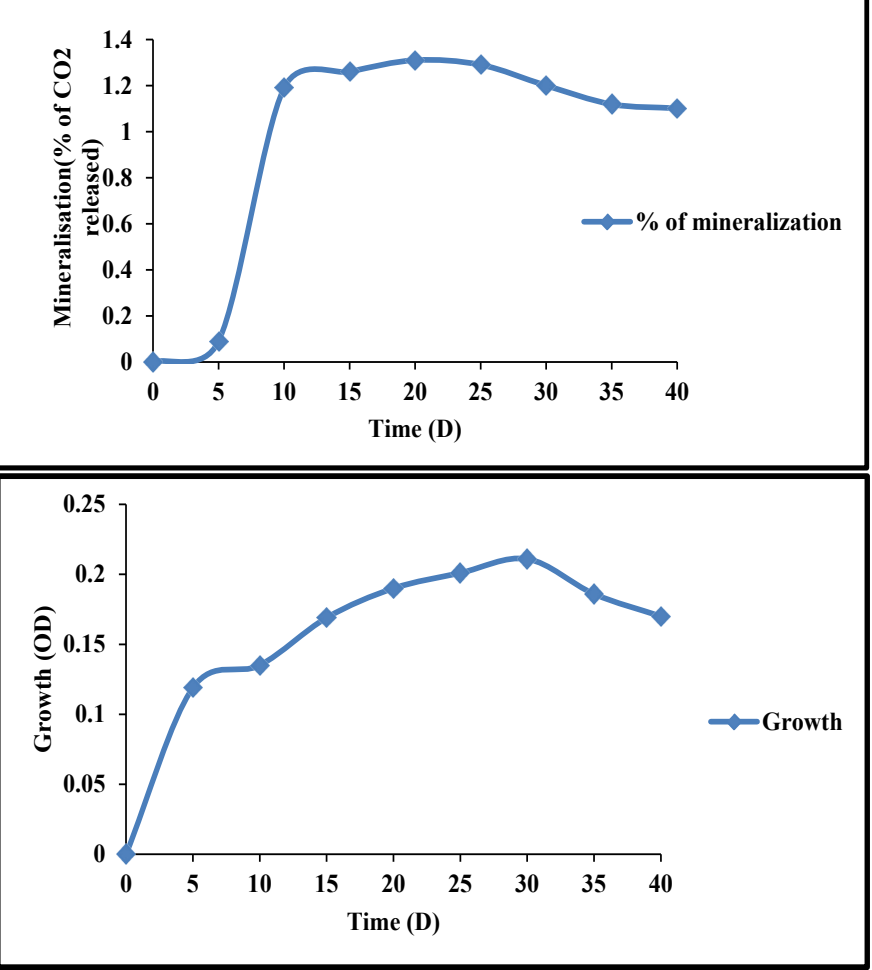

Figure 10. Mineralisation of synthetic rubber gloves by the bacterial consortium.
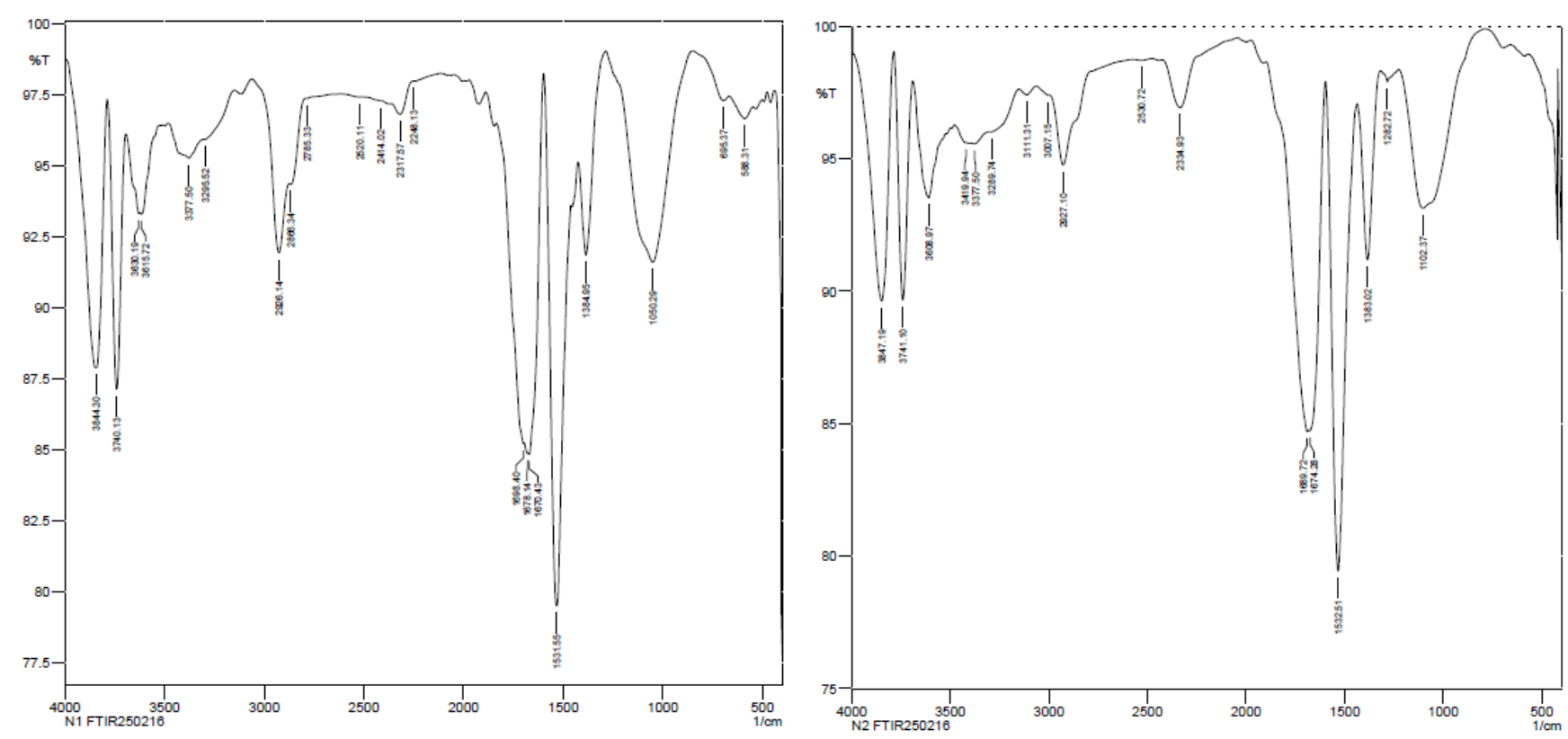

Figure 9. Conformation of NR mineralisation by FTIR.

consortium served as abiotic control. The Synthetic rubber degradation was studied for 40 days and the mineralization was observed as distortions. Their growth pattern was monitored by means of growth OD values $(0.211)$ which shows that there was constant increased in their growth till 30 days after which the growth decreased. Maximum mineralization was observed on $20^{\text {th }}$ day $\left(1.3 \times 10^{-4}\right)$ and maximum growth of 0.211 was observed on $30^{\text {th }}$ day. Figure 10 shows mineralisation of SRG by the isolated Bacterial consortium.

\section{Staining of rubber degrading colonies by Schiff's reagent method}

SRG which were inoculated with bacterial consortium turned to purple colour and there was no colour formation in the control. 
Formation of purple colour in the mineralized sample is due to the presence of aldehyde and ketone group which is produced as a result of degradation of cis-1, 4-polyisoprene units. Figure 11 shows the production of aldehydes by Schiff's reagent test.

\section{Effect of pre-treatment of the synthetic rubber gloves on the mineralization of $S R G$}

Effect of pre-treatment on the mineralisation was observed by visualising the distortions caused due to the growth of the bacterial consortium on the synthetic rubber gloves as the sole carbon source.

\section{Scanning electron microscopy (SEM) for analysis of distortion in SRG}

Distortions caused due to mineralisation were observed under Scanning Electron Microscopy (SEM). Most prominent distortions were observed on the sunlight treated SRG next was of the acetone treated and the least was of the untreated SRG. Figure 12 shows the SEM micrographs of sunlight pre-treated SRG. Figure 12a SEM micrograph of uninoculated SRG, Figure 12b SEM micrograph at $100 \mu \mathrm{m}$ showing the distortion, Figure 12c SEM micrograph at $40 \mu \mathrm{m}$ showing the distortion. Figure 13 shows the SEM micrographs of acetone pre-treated SRG. Figure 13a SEM micrograph of uninoculated SRG, Figure 13b SEM micrograph at $100 \mu \mathrm{m}$ showing the distortion, 13c SEM micrograph at $40 \mu \mathrm{m}$ showing the distortion. Figure 14 shows the SEM micrographs of untreated SRG. Figure 14a SEM micrograph of uninoculated SRG, Figure 14b SEM micrograph at $100 \mu \mathrm{m}$ showing the distortion, Figure 14c SEM micrograph at $40 \mu \mathrm{m}$ showing the distortion.

\section{Scanning electron microscopy (SEM) analysis of the bacterial strains}

SEM analysis was carried out to study the variation in morphological structures of both the individual bacterial as well as the bacterial consortium on mineralisation. The ultrastructure of the bacterial strains was observed under 11000 $\mathrm{X}$ magnification. Figure 15 shows the structure of the bacterial strain NPKVG 1, NPKVG 2, NPKVG 3 and the bacterial consortium respectively under $11000 \mathrm{X}$ magnification. It was seen that the individual bacterial strains NPKVG 1, NPKVG 2, NPKVG 3 and the consortium showed rod shaped morphology (Figure 16).

\section{Molecular Identification of the Bacterial Strains}

\section{DNA isolation and PCR amplification}

The genomic DNA was isolated from each bacterial isolates (Table 2). PCR amplification was performed and the unknown bacterial strains were identified through $16 \mathrm{~s}$ r-DNA sequencing. The bacterial isolates were identified from the sequence using blast tool. Genomic DNA and PCR amplified products of the three bacterial isolates are shown in Figure 17.

\section{6s rRNA sequencing and phylogenetic analysis}

The identification of the bacterial strains was done by using blast tool available in the NCBI database. The sequences of the individual bacterial strains obtained from the $16 \mathrm{~s}$ rRNA sequencing were added in the blast software. The bacterial

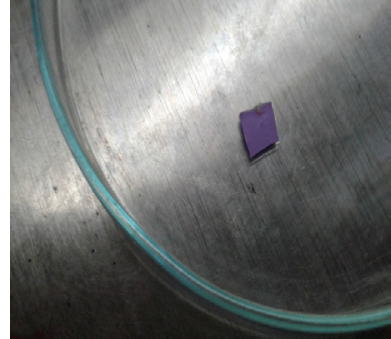

CONTROL-SRG

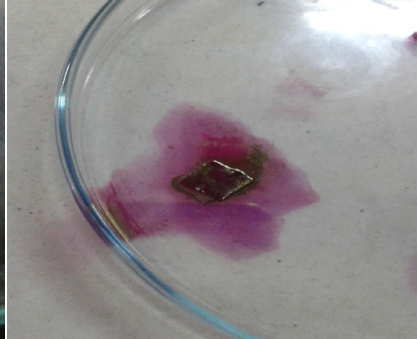

MINERALIZED-SRG
Figure 11. Production of Aldehydes by Schiff's reagent test.

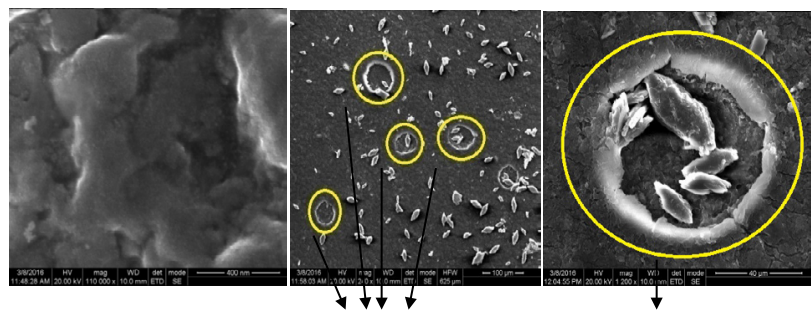

a) Control

b) Distortion at100

c) Distortion at $40 \mu \mathrm{m}$

Figure 12. SEM micrographs of sunlight pre-treated SRG.

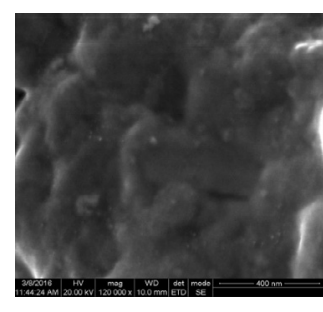

a) Control

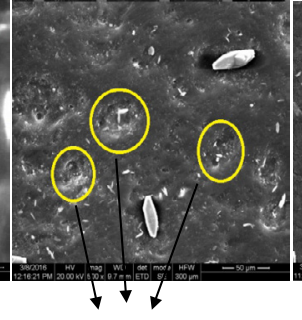

b) Distortion at100

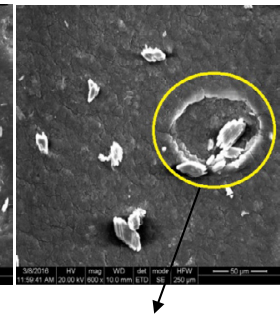

c) Distortion at $40 \mu \mathrm{m}$
Figure 13. SEM micrographs of acetone pre-treated $S R G$.

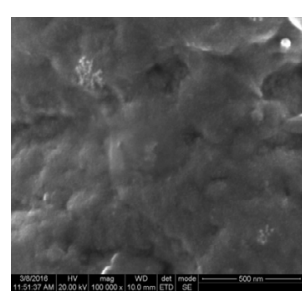

a) Control

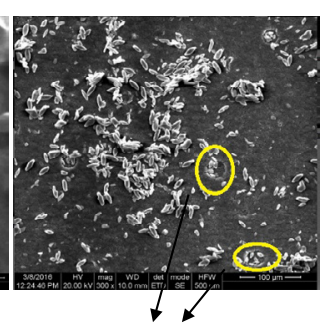

b)Distortion at100 $\mu \mathrm{m}$

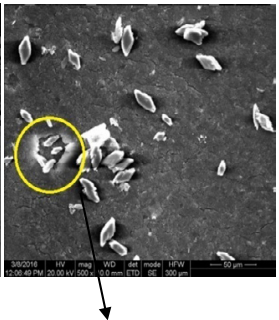

c) Distortion at $40 \mu \mathrm{m}$
Figure 14. SEM micrographs of untreated SRG.

isolate NPKVG 1 was identified as Enterobater cloacae, NPKVG 2 as Microbacterium laevaniformans and NPKVG 3 as Methylobacterium rhodesianum.

The evolutionary relationship between the bacterial strains was determined by constructing a phylogeny tree. The sequences obtained were first converted into a FASTA format and the phylogeny tree was then converted by using the software mega 6.0. Figure 18 shows the phylogeny tree of the individual bacterial strains.

\section{Discussion}

Rubber products are widely used in our daily life these products are mainly made up of Natural rubber (NR) which is obtained from the latex of tree Hevea brasiliensis commonly called Rubber tree. The average composition of the natural rubber latex is $25-30 \%$ polyisoprene, $1-1.8 \%$ proteins, $1-2 \%$ carbohydrates, 


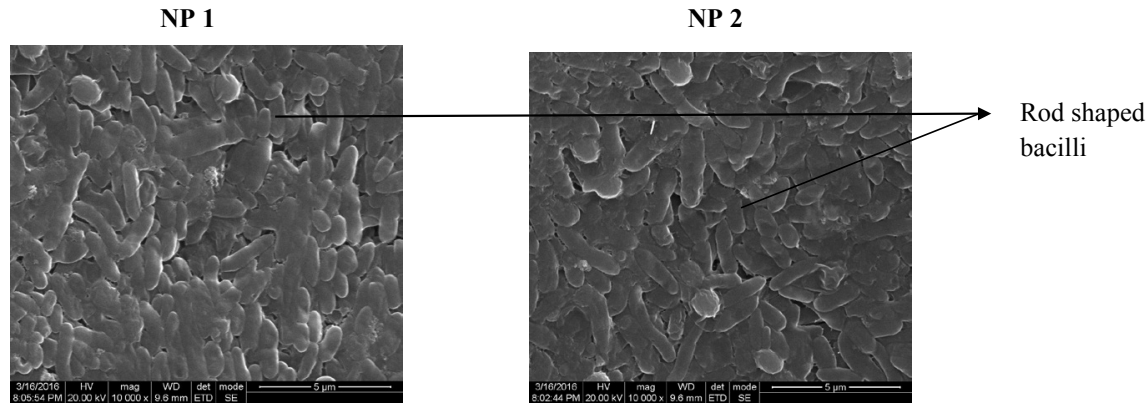

NP 3 CONSORTIUM

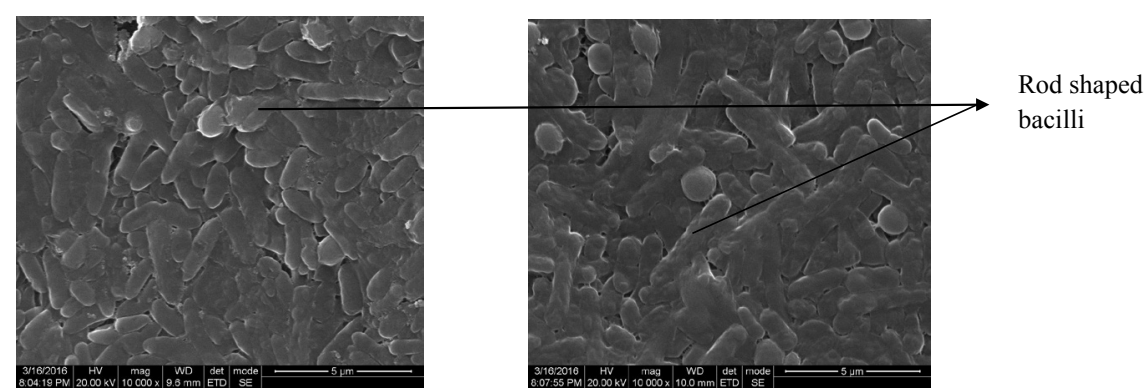

Figure 15. Morphology of the individual bacterial strains and consortium under $11000 x$ magnification.

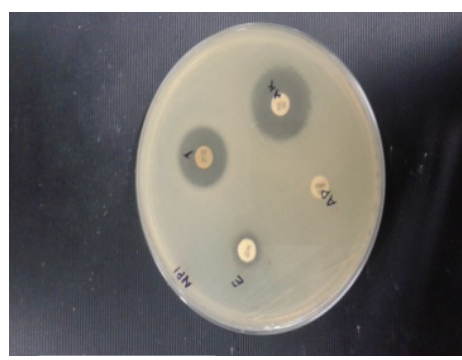

NPKVG1

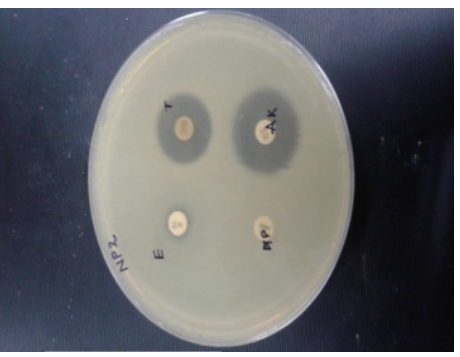

NPKVG2

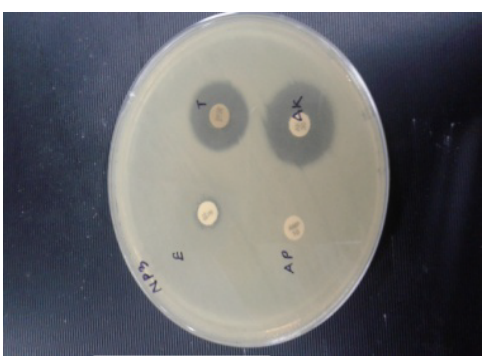

NPKVG2

Figure 16. Shows antibiotic sensitivity tests by isolated bacterial consortium.

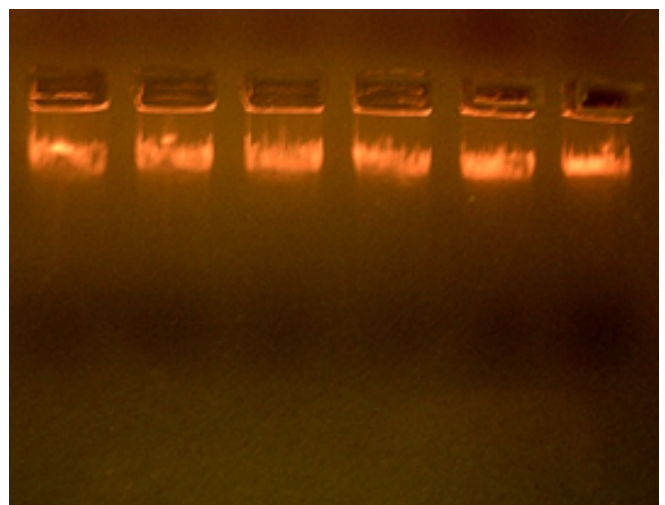

Figure 17. Genomic DNA and PCR amplified products; lane $1=$ genomic DNA of NPKVG1; lane 2=PCR amplified product of NPKVG2; lane $3=$ genomic DNA of NPKVG3.

0.4-1.1\% neutral lipids, 0.5-0.6\% polar lipids, 0.4-0.6 inorganic components, $0.4 \%$ amino acids etc., and other $50-70 \%$ water. Solid waste management of the natural rubber products becomes the most important problem.

One of the solutions to reduce this problem is to reuse the used rubber. But due to the chemical cross linking formed during vulcanization it is not possible to simply melt and reshape the products as in case of polythene. So other alternatives such as microbial degradation of the product should be developed which is more eco-friendly technique. Microbial degradation is mainly carried out by various microorganisms such as bacteria and fungi [23].

There are number of literature reports on the microbial deterioration of Natural rubber by Bacterial and Fungal isolates. 
Table 2. Antibiotic susceptibility test for all three bacterial isolates.

\begin{tabular}{|c|c|c|c|}
\hline Antibiotics disc & NPKVG1 & NPKVG2 & NPKVG3 \\
\hline $\begin{array}{l}\text { Tetracyclin }(30 \mu \mathrm{g} / \\
\text { disc) }\end{array}$ & $6 \mathrm{Mm}(\mathrm{s})$ & $7 \mathrm{~mm}$ (s) & $6 \mathrm{~mm}(\mathrm{~s})$ \\
\hline $\begin{array}{c}\text { Erythromycin } \\
(15 \mu \mathrm{g} / \mathrm{disc})\end{array}$ & $-(r)$ & $-(r)$ & $-(r)$ \\
\hline 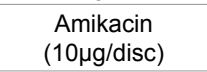 & $8 \mathrm{~mm}(\mathrm{~s})$ & $8 \mathrm{~mm}(\mathrm{~s})$ & $8 \mathrm{~mm}(\mathrm{~s})$ \\
\hline $\begin{array}{l}\text { Ampicillin }(10 \mu g / \\
\text { disc) }\end{array}$ & $-(r)$ & $-(r)$ & $-(r)$ \\
\hline
\end{tabular}

Note: $s=$ sensitive; $r=$ resistance; $-=$ no zone of lysis

Most of the literature reports are on mineralisation of Bacterial and Fungal isolates as individual cultures. Hence in the present study an attempt has been made for the isolation of NR degrading Bacterial consortium which was effectively able to utilize both NR and SRG. In the present study 3 bacterial strains were isolated and were identified as Enterobacter coloacea, Microbacterium laevaniformans and Methylobacterium rhodesianum.

Nayanshree et al. [24] isolated bacterial strain Bacillus pumilus which showed the capacity of degrading Natural rubber disc. Initial weight of the sample inoculated in MSM with Bacillus pumilus was $3 \mathrm{~g}$ which was reduced to $2.28 \mathrm{~g}$, a total weight loss of $24 \%$. In the present study the Bacterial consortium from the contaminated site which was able to utilise NR from the concentration of $1 \%$ to $5 \%$ and it was observed that $1 \%$ shows the maximum mineralisation $\left(1.66 \times 10^{-4}\right)$ on the $4^{\text {th }}$ day of incubation.

Onyeagoro et al. showed the determination of intrinsic viscosity which can be used to find the molecular weight of natural rubber latex $[25,26]$. This was done by finding the specific viscosity of the viscous liquid calculated from the time taken each sample in an Ubbelohde capillary viscometer. In the present study molecular weight of the NR latex was also calculated using Ubbelohde capillary viscometer. The molecular weight of the
NR latex used in the present study showed 21379.62.

Glucose, fructose and arabinose supplementation has been reported to lower the extent of degradation while for the isolates it was almost not affected when lactose was supplemented in the medium [27]. Tween $80(1 \%)$ has earlier been reported to increase the production of lipase from Bacillus sp. Effect of cometabolites (Tween 20, Tween 80 , glucose and yeast extract) on the degradation of polyurethane was checked. Both esterase and lipase activity were maximum in the presence of glucose. Lipase activity decline after 1 st week till end in the presence of Tween 80 whereas esterase activity increased after 2 nd week till end in the presence of Tween 80 . In the present study, rubberdegrading bacterial consortium was enriched by different carbon sources (sucrose, lactose, xylose, and maltose) and nitrogen (peptone, ammonium nitrate, yeast extract, ammonium oxalate) sources. From the experiments performed in the present study it was found that ammonium oxalate served as a better nitrogen source that enhances the mineralisation of latex at its maximum $\left(1.71 \times 10^{-4}\right)$ by the bacterial consortium. Likewise, xylose as a carbon, which was found to be the best carbon source giving maximum mineralisation $\left(1.54 \times 10^{-4}\right)$ that could enhance the mineralisation of natural rubber.

Nayanshree et al. [28] analysed the degradation of natural rubber by carrying out growth study in MSM, and mineralisation was confirmed by staining with Schiff's reagent, SEM, \& FTIR studies. Peaks were observed at $1662.34 \mathrm{~cm}^{-1}$ having $\mathrm{H}-\mathrm{C}=\mathrm{O}$, $\mathrm{C}-\mathrm{H}$ stretch and $\mathrm{C}-\mathrm{O}$ stretch which indicates the presence of aldehydes and ketones which confirms the degradation of rubber. In their study peaks of NR mineralisation were observed at $1646 \mathrm{~cm}^{-1}$ and $1651 \mathrm{~cm}^{-1}$ having $\mathrm{H}-\mathrm{C}=\mathrm{O}, \mathrm{C}-\mathrm{H}$ stretch and $\mathrm{C}-\mathrm{O}$ stretch which indicates the presence of aldehydes and ketones which confirms the degradation of rubber. In the current work NR degradation was carried out in MSM supplemented with

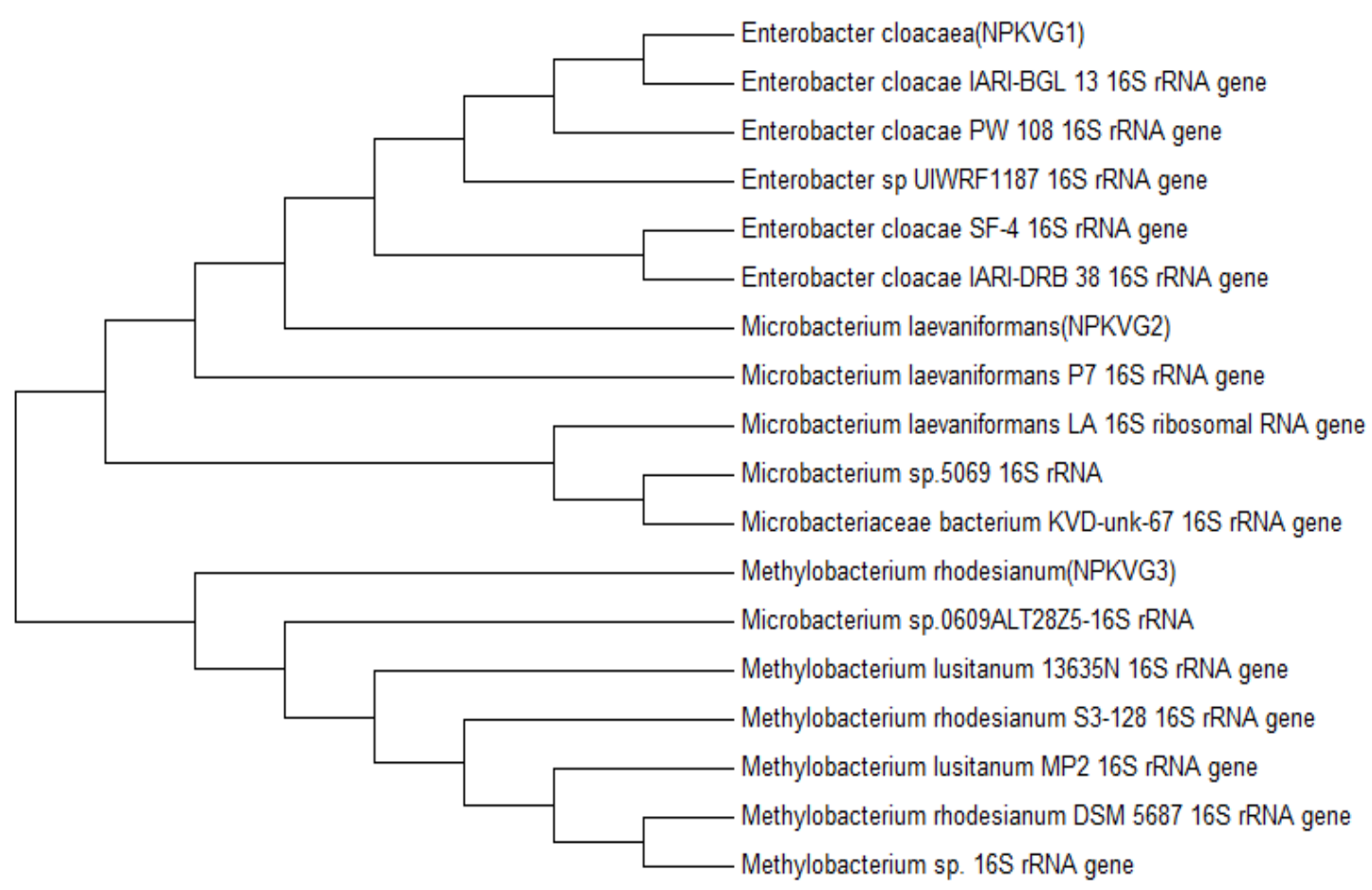

Figure 18. Phylogenetic tree analysis of the bacterial strains. 
rubber latex as the carbon source and the bacterial consortium. Degradation was confirmed by FTIR analysis, peaks were observed C-H Stretching, C-O Stretching and C-N Stretching which indicates the presence of aldehydes and ketones which confirms degradation of NR which was again proved by Schiff's reagent $[29,30]$.

In the mineralisation of Synthetic rubber gloves it was observed that till the $30^{\text {th }}$ day growth of the Bacterial consortium increased after which it depleted. The bacterial consortium was able to form a biofilm on the latex gloves when SR was used as a substrate, hence they were able to use SR as carbon source and distortion was seen by Scanning Electron Microscopy.

Aamar Ali Shah et al. [31] studied the effect of pre-treatment of artificial rubber on the degradation process. The rubber samples were pre-treated with Sunlight, Acetone and UV-Light. The rate of degradation was analyse by measured the weight loss of the sample during mineralisation and by FTIR analysis. In the present study the effect of pre-treatment of SR on the degradation of SR was analysed and it was confirmed by staining with Schiff's reagent and Scanning Electron Microscopy [32].

\section{Conclusions}

Complex nature of the polymers make it very difficult to degrade, as the only solution in reusing them is by incineration process when it is melted they don't reshape in to their original structures.

Therefore, it is important to find a more economic and environmentally friendly treatment method, for which microbial degradation may be competitive method. The present study result shows that the bacterial consortium which was isolated from the effluent contaminated soil was able to mineralize natural rubber latex. The bacterial consortium was optimized for their growth parameters $(\mathrm{pH}$, temperature, carbon, nitrogen and mixed carbon and nitrogen sources). The isolated bacterial consortium could efficiently mineralize up to $5 \%$ concentrations of NR latex. It could also be applied in the distortions of SRG within a period of one month we could get maximum distortion. Such promising bacterial consortium could be applied in the removal of rubber contaminated soil, which is eco-friendly and cost effective method compared to physico-chemical methods. Further such efficient bacterial consortium can be used in the remediation of solid waste which is said to be the potential threat to the environment. This research area could be further extended on the focus on the gene transfer mechanisms on the bacterial strains and on the biofilm production. Extended work on the study of the biofilms on the degradation of artificial rubber would facilitate the development of better techniques for the bioremediation of rubber polluted sites and wastewaters.

\section{References}

1. Rose K, Steinbuchel A. Biodegradation of natural rubber and related compounds: Recent insights into a hardly understood catabolic capability of microorganisms. Applied and Environmental Microbiology. 2005;71:2803-12.

2. Rose K, Tenberge KB, Steinbuchel A. Identification and characterization of genes from Streptomyces sp. strain
K30 responsible for clear zone formation on natural rubber latex and poly (cis-1, 4-isoprene) rubber degradation. Biomacromolecules. 2005;6(1):180-88.

3. Heinz-Hermann G. "Rubber, 2. Natural" in Ullmann'sEncyclopedia of Industrial Chemistry. WileyVCH, Weinheim. 2000.

4. Linos A, Berkaa MM, Reichelt R, et al. Biodegradation of cis-1, 4-Polyisoprene Rubbers by distinct Actinomycetes: Microbial strategies and detailed surface analysis. Applied and Environmental Microbiology. 2000;66:1639-45.

5. Tsuchii A, Takeda K, Tokiwa Y. Colonization and degradation of rubber pieces by Nocardia sp. Biodegradation. 1996; 7:41-8.

6. Tsuchii A, Tokiwa Y. Microbial degradation of Tire rubber particles. Biotechnology Letters. 2001;23:963-69.

7. Bode H, Kerkhoff K, Jendrossek D. Bacterial degradation of natural and synthetic rubber. Biomacromolecules. 2001;2:295-303.

8. Tsuchii A, Suzuki T, Takeda K. Microbial degradation of natural rubber vulcanizates. Appl Environ Microbiol. 1985;50:965-70.

9. Mahmoud M, Berekaa A, Alexandros Linos A, et al. Effect of pretreatment of rubber material on its biodegradability by various rubber degrading bacteria. FEMS Microbiology Letters. 2000;184:199-206.

10. Tsuchii A. Microbial Degradation of Natural Rubber. In Biotransformation: Microbial Degradation of Health Risk Compounds (Singh, Ved Pal. Edition). Progress Ind Microbiology. 1995;32:177-87.

11. Heisey RM, Papadatos S. Isolation of microorganisms able to metabolize purified natural rubber. Appl Environ Microbiol. 1995;61:3092-97.

12. Jendrossek D, Tomasi G, Kroppenstedt RM. Bacterial degradation of natural rubber: a privilege of actinomycetes? FEMS Microbiol Lett. 1997;150:179-88.

13. Manasa Muralidharan, Veena Gayathri K. Mineralisation of natural rubber (poly cis 1-4 isoprene) by co-cultured bacterial strains isolated from rubber plantation area. International Journal of Biological Research. 2016;4(1):1-9.

14. Muralidharan M, VeenaGayathri K. Artificial Rubber mineralisation by co-cultured bacterial strains. International Journal of Biological Research. 2016;4(2):105-11.

15. Low FC, Tan AM, John CK. Microbial degradation of natural rubber. Journal of Natural Rubber Research. 1992;7(3):195-205.

16. Warneke S, Arenskotter M, Tenberge KB, et al. Bacterial degradation of poly (trans-1, 4-isoprene) (Guttapercha). Microbiology. 2007;153(2):347-56.

17. Shah AA, Hasan F, Akhter JI, et al. Degradation of polyurethane by novel bacterial consortium isolated from soil. Annals of Microbiology. 2008;58:381. 
18. Roy VR, Das M, Banerjee R, et al. Comparative studies on rubber biodegradation through Solid state and sub-merged fermentation. Process Biochemistry. 2005;42:181-86.

19. Arvanitoyannis I, Kolokuris I, Nakayama A, et al. Preparation and study of novel biodegradable blends based on gelatinized starch and 1,4-transpolyisoprene (guttapercha) for food packaging or biomedical applications. CarbohydrPolym. 1998;34:291-302.

20. Tsuchii A, Takeda K. Rubber-degrading enzyme from a bacterial culture. Applied and Environmental Microbiology. 1990;56(1):269-74.

21. Arenskotter M, Vaumeister D, Bereka MM, et al. Taxonomic characterization of two rubber degrading bacteria belonging to the species Gordonia polyisoprenivorans and analysis of hyper-variable region of 16s r-DNA sequences. FEMS Microbiology Letter. 2001;205:277-82.

22. Berekaa MM, Barakaat A, El-Sayeed SM, et al. Degradation of Natural Rubber by Achromobacter sp. NRB and Evaluation of culture conditions. Polish Journal of Microbiology. 2005;54(1):55-62.

23. Nayanashree G, Thippeswamy B. Natural Rubber Degradation by Aspergillus niger and Penicillium sp. International Journal of Recent Scientific Research. 2013;4(9):1337-41.

24. Nayanashree G, Thippeswamy B, Krishnappa M. Natural Rubber Biodegradation by Cladosporiumfulvumand Enzymes responsible for Biodegradation. International Journal of Advanced Research. 2014;2(4):1206-12.

25. Ibrahim EMA, Arenskotter $\mathrm{M}$, Luftmann $\mathrm{H}$, et al. Identification of poly (cis-1,4- isoprene) degradation intermediates during growth of moderately thermophilicactimycetes on rubber and cloning of a functional ICP homologue from Nocardiafarcinica strain EI. Applied Environ Microbiology. 2006;72:3375-82.

26. Karsten R, Alexander S. Biodegradation of Natural Rubber and Related Compounds: Recent Insights into a Hardly Understood Catabolic Capability of Microorganisms. Appl Environ Microbiol. 2005;71(6):2803-12.

27. Manna A, Paul AK. Degradation of microbial polyester poly (3-hydroxybutyrate) in environmental samples and in culture. Biodegradation. 2000;11:323-29.

28. Nayanashree G, Thippeswamy B, Krishnappa M. Enzymatic studies on Natural rubber biodegradation by Bacillus pumilus. International Journal of Biological Research. 2014;2(2):44-47.

29. Linos A, Steinbuchel A. Biodegradation of natural and synthetic rubber. In: Koyama T, Steinbuchel A (editors) Biopolymers. Wiley-VCH, Weinheim, Germany. 2001:321-59.

30. Linos A, Berekaa MM, Syeinbuchel A, et al. Gordoniawestfalicasp. nov., a novel rubber-degrading Actinomycete. International Journal of Systematic and Evolutionary Microbiology. 2002;52(4):1133-39.

31. Aamer Ali S, Fariah H, Hameed A, et al. Biodegradation of plastics: A Comprehensive Review. Biotechnology Advances. 2008;246-65.

32. Ziaullah S, Ali Shah A, Hameed A, et al. Effect of pretreatments on enhanced degradation of polyisoprene rubber by newly isolated Bacillus sp. Strain S10. Journal of the Chemical Society of Pakistan. 2009;31(4):638-46.

\section{*Correspondence to:}

Krishnaswamy Veenagayathri

Department of Biotechnology

Chennai-83

India

Tel: +91 9940412363

E-mail: veenagayathri@yahoo.com 